\title{
Research on the Internationalization and the Localization of China's MBA Education
}

\author{
Jie Lin ${ }^{1, *} \&$ Haiyong $\mathrm{Ma}^{1}$ \\ ${ }^{1}$ School of Economics and Management, Changchun University of Science and Technology, Changchun 130022, \\ China \\ *Corresponding author: School of Economics and Management, Changchun University of Science and Technology, \\ 7989, Weixing Road, Changchun 130022, Jilin Province, China. E-mail: mhymark@gmail.com
}

Received: October 10, $2012 \quad$ Accepted: November 4, $2012 \quad$ Online Published: November 20, 2012

doi:10.5430/wje.v2n6p20 URL: http://dx.doi.org/10.5430/wje.v2n6p20

This paper is one of phased achievements of the Project "Research on the Harmonious Development of the Internationalization and the Localization of MBA Education in Colleges and Universities of Jilin Province" (GH11121), a "12th Five-Year" Planning Project of Education Science of Jilin Province.

\begin{abstract}
This article started with a brief review of the history and current situation of Chinese MBA education and its internationalization and localization. Then, the author presented the opportunities faced of China's MBA education. Furthermore, the challenges faced by Chinese MBA education in the globalization process together with their implications were also discussed. At the end of this paper, the author gave some recommendations on the reforms and innovations for the Localization and internationalization of MBA education in China.
\end{abstract}

Keywords: MBA education; Internationalization; Localization

Since the birth of MBA in Harvard Business School in 1908, MBA has been a hundred years of history, while the introduction of MBA into China has been only twenty years. In China, the traditional management follows the code of "no changes for ruling, no changes for rules", striving for the organizational and social stability. It emphasizes on the overall situation, adheres to appropriate moderation, and seeks for the common ground while respecting differences. This management idea seriously damages the innovation power of China and would eventually restrain the development of national corporations, under the circumstance of open market economy. The United States aims at training the combat management personnel by developing the MBA education. This objective is perfectly fitting China's needs for fast economic development. To introduce the MBA education can bring Chinese managers not only the innovative management knowledge, but also, more precisely, an unprecedented way of thinking. It revolutionizes the management thinking and optimizes the management efficiency. However, China's MBA education has a long way to go. A series of problems show up during its rapid development process, what makes the MBA education in China face severe challenges.

\section{The internationalization and the localization of MBA education}

Internationalization refers to a concept of certain consistency universal in the world, after abstracting all language, country, region, and culture-related elements. With regard to the meanings of the internationalization of higher education, the academia holds various versions. For the MBA education, the internationalization of MBA education means China's MBA education should share the same platform with other countries' MBA education, especially the western developed countries' MBA education, i.e. China's MBA education should be universal, international, and comparable.

The localization concept is closely related with the internationalization concept and the globalization concept. It appears under the condition of economic globalization. No economic globalization, no localization. For the MBA 
education, the localization of MBA education means the MBA education must take China's conditions into consideration, including China's specific environment and Chinese students.

In short, the internationalization of MBA education refers to the popularity of MBA education, and the localization of MBA education refers to the adaptability of MBA education.

\section{The development of China's MBA education}

When the MBA education entered China in 1991, China was at the important moment for the transition of economic system. At that time, the MBA education was only a concept for Chinese entrepreneurs. With the rapid economic development, the need for achieving economic benefits by optimizing the management appears in Chinese enterprises, which provides chances for the fast development of MBA education in China. Currently China has $6,000,000$ enterprises, of which 360,000 enterprises respectively produce the annual output value of more than $5,000,000$ Yuan. All these enterprises need a large number of professional managers with real-world experiences and systematic theories. Particularly with the separation of corporate ownership and management, the need for enterprise management personnel is expanding.

China's MBA education, starting from the year 1991, has gone through more than twenty years, experiencing the changes from exploration to imitation and to localization, and achieving a lot of achievements. In 1991, only 9 institutions made pilot MBA education. In 2010, the number rose to 236, expanding by 26 times. In 1991, only 94 students were enrolled. In 2010, the number exceeded 36,000, expanding by 383 times. These basic data show that the "three-increasing" phenomenon arises in the development of MBA education, i.e. the increasing institutions for MBA education, the increasing enrolled students, and the increasing enterprise needs.

Among the latest Fortune 500 companies released by the magazine "Fortune", published in July 2011, 58 Chinese mainland enterprises are in the list. Apparently, Chinese enterprises have occupied an increasingly important position on the international economic stage. Business management determines the success of the failure of the enterprise in a great extent. The management guru Peter Drucker once said that managers must transform the social needs into corporate profit opportunities. The MBA education is to train this kind of managers, namely the managers with a sense of innovation. The contribution of MBA education to China is not only to spread the management knowledge and theories, but also, more importantly, to promote the innovation and development of Chinese enterprises. In the future, China will be more in need for the professional management personnel in order to make business management more efficient.

\section{The challenges for the development of China's MBA education}

Although China's MBA education has made a series of achievements, it is still immature and at the early stage of development in general. Under the surface prosperity of rapid expansion of size, there is a crisis of continuous depreciation of MBA talents. China's MBA education is facing a series of challenges in the development process. There are more spaces for its growth in quality and quantity. China's MBA education market has not yet developed a perfect free market competition mechanism. Relevant departments of the Government have set strict entrance requirements for the educational institutions of MBA education. However, the MBA education was the product of market economic development originally. Only by returning to the market, can it play its due role. The current evaluation system for MBA education cannot directly reflect the market evaluation of the teaching, which is actually replaced by the evaluation of the educational management department of the Government.

The MBA programs have a serious problem of homogenization. They arrange similar curriculums and the teaching covers too much fields but seldom makes deep research. Therefore, these programs cannot achieve the objectives of MBA education. The teaching materials are similar in both structure and contents and the case studies are basically the same. Under this circumstance, the MBA education can only produce the standard products on the assembly line but not make business managers with creativity and rich experiences. In addition, the outdated teaching methods, the inappropriate student candidates, and the poor quality of teaching staff affect the quality of MBA education to varying degrees. Since the MBA education was imported from outside at the very beginning, the learning concept of "borrowing" has wasted the opportunity for China's MBA education developing the local features to some extent. A controversy over the localization and the internationalization of MBA education has become a hot topic for the reflection of China's MBA education after the Wall Street financial crisis in 2007. The global crisis triggered by the U.S. subprime mortgage crisis makes the entrepreneurs and the educators begin to question the western economic theories and business management pattern. Plus China's particular political system, 
economic environment, as well as the unique situations of business community, we agree that China's MBA education should get rid of the blind pursuit for internationalization and the defect of lacking innovative localization.

In the world, along with the expansion of MBA education, the teaching quality gains more and more attentions. In 2004, Mintzberg published a research report Managers Not MBAs. Mintzberg and his assistant tracked 19 distinguished MBAs on the list from the Inside the Harvard Business School published in 1990. They observed their long-term performances as CEOs. It turned out that 10 of the 19 MBAs failed obviously by the end of 2003. They were swept out after bring vital disasters to companies. They ended in useless. Other 4 MBAs were questioned about their competence. Only 5 of them did very well. Mintzberg made deep reflections over the traditional MBA education in his report, i.e. recruiting the wrong people, using the wrong ways, and performing the wrong business practices.

After entering the $21^{\text {st }}$ century, especially since the outbreak of the global economic crisis in 2007, the MBA education in Europe and the United States has been facing a new round of reflection. Lots of enterprises have been closed down. Previous effective management patterns could not save enterprises from bankruptcy. The business community began to question whether the classic management theories were just a bunch of flashy words. The management guru Peter Drucker once said that management was a practice, its nature was not about knowing but about practicing, its demonstration was not about logics but about the outcome, and the only authority was the achievement. How to train the MBA students and make them achieve business success? What on earth does the MBA education try to teach the students, the management classic popular for centuries or the management tools popular now, the leadership, the corporate social responsibility, and other hot topics, or the production operations, finance, marketing, and other basic corporate activities, the professional managers who are capable of dealing with the changes of business world, or the entrepreneurs who can create a new career? All these issues deserve more profound reflections of China's MBA education.

\section{The reforms and innovations of China's MBA education}

The original intention of MBA education is to develop excellent business managers, which is rightly the core driving force that arouses the reform of China's MBA education. Educational reform is seldom triggered from inside. It needs external driving force. At present, China is at the key moment for economic transition and industrial updating, which requires that China's MBA education must adapt to the situations and strive to make reforms and innovations.

The key for China's MBA education's reform and innovation should focus on the market-orientation, professionalization, features, localization, and internationalization.

China's MBA education should take the market-oriented development and introduce the market competition mechanism. The Government should widen the entrance for MBA education institutions and attract powerful education institutions to join in the MBA education cause, leaving the evaluation and assessment work to the market. At the same time, the Government should strengthen the supervision and provide encouragement and guidance for various innovations and tries the process of entering and adapting to the market. Different MBA programs should follow the professional and special development path. Except for focusing on the training outcome for MBA students, they should know how to adapt to diversified market demands. They can provide different MBA special programs according to their conditions and features, giving tailored trainings to the management talents for enterprises. For example, make curriculum arrangement according to the special requirements for different industries, such as real estate, machinery, mining, and finance, achieve the targeted and professional trainings, and continue to explore the depth and the width of MBA education.

We should organically combine the internationalization and the localization of MBA education together, and should not ignore any of them. China's MBA education institutions should make joint exploration with world famous business schools on international cooperation projects in order to strengthen the international outlook and the global strategic thinking of MBA students. These Sino-Foreign cooperative MBA programs can selectively introduce some foreign advanced textbooks, arrange the cooperation curriculums based on international practice, and actively learn the training plans, teaching plans, teaching materials, teaching modes, and management experiences from foreign cooperators who possess educational advantages. The combination of internationalization and localization can help to train the business management talents who are familiar with the operation of international market, possess modern corporate management capabilities, and know local market.

The reform and innovation of China's MBA education need powerful explorations on certain micro aspects, 
such as the teaching methods, curriculum, student candidates, and teaching faculty.

At present, the main disadvantages of China's MBA teaching methods can be summarized as follows: too much teaching, but insufficient interactions; too much theories, but insufficient practices; case studies are simple, but not local; curriculum arrangement is not general or continuous, lacking of multi- disciplinary and multi-field cross penetration. We should strengthen case studies, group discussions, multimedia simulations, and other teaching methods. Meanwhile, we can focus on the management practice outside the classes, deepen the understandings of theories, and improve the capabilities of manipulating the management knowledge.

Teaching by case studies is an important component of MBA teaching. MBA students can learn the thinking of solving problems by analyzing the simulation cases, which requires cases to be good simulations. Only by this way, the accuracy of putting cases back to realities can be guaranteed. However, the cases used by current MBA teaching are seldom designed by Chinese scholars, and most are relatively simple and rough. Although the cases used by foreign business schools are classic, these cases are not even close to Chinese corporate practices. One of the main directions of China's MBA education development would be replacing academic theoretical analysis with local case studies, building Chinese case bases, advocating experiences of localization, and emphasizing on cultivation of the spirit of innovation.

The teaching faculty is the main force to improve MBA teaching quality. The MBA teaching requires that the teachers should have good academic foundations and rich practical experiences. Therefore, MBA education institutions should take the faculty as the backbone and absorb senior corporate managers who possess rich practical experiences, theoretical knowledge, and educational enthusiasm from enterprises as lecturers, enriching the part-time teaching team. Meanwhile, the institutions should break the sectarianism, overcome the constraints of system, promote the communication of MBA teachers, and achieve the sharing of resources of high-quality teachers. To strengthen the connection and the cooperation of institutions and enterprises is also an important way of improving the usefulness of MBA education.

As for the enrollment of students, we should focus on examining students' management experiences and development potentials, following the elite development path. The MBA education should target at the "semi-product" instead of "raw material". The original intention of the MBA education is to provide theoretical guidance for business elites who have some practical experiences, help them to refine their management experiences and achieve the upgrade from quantitative changes to qualitative changes, and improve their management capabilities. However, in China the MBA students tend to be younger, with lower income. Students' personal qualities and innovation capabilities produce new challenges to the MBA teaching. At present, the MBA entrance examination sets higher score for the written test, while the test is short of sections that need comprehensive analysis. Thus, a large number of excellent elderly student candidates who have rich management experiences cannot pass the written test. Therefore, changing the current written test-oriented recruitment, reforming the test contents, expanding the proportion of balance admission, and increasing the weight of interview should be an important direction for the reform of China's MBA education.

\section{References}

Cui, Hongwei. (2012). The localization and internationalization of China's MBA education. Chinese and Foreign Entrepreneurs, 1 .

Wang, Minghui. (2008). The quality assessment and management analysis of MBA education in the United States. China Adult Education, 2.

Wang, Wenchao. (2007). The comparison research on the MBA education of China and oversea. Science-Technology and Management, 4.

Zheng, Shaolian. (2000). The MBA education should not replace internationalization with localization. China Higher Education, 21. 